\title{
Studies on mosquitoes (Diptera: Culicidae) and anthropic environment. 6 - Breeding in empty conditions of rice fields in South-Eastern Brazil*
}

\author{
Oswaldo Paulo Forattini**, Iná Kakitani**, Eduardo Massad***, Daniel Marucci** \\ FORATTINI, O.P. et al. Studies on mosquitoes (Diptera: Culicidae) and anthropic environment. \\ 6 - Breeding in empty conditions of rice fields in South-Eastem Brazil. Rev. Saúde Pública, 28: 395 - \\ 9,1994 . Studies on culicid breeding in empty rice fields were carried out during the cultivation cycle \\ from May to November 1993. This period corresponded to stages 1 and 2, when empty conditions \\ prevailed. Breeding occurred in stage 1 and the first part of stage 2, corresponding respectively to \\ fallow uncultivated and ploughing situations. No breeding was found to take place during the second \\ part of stage 2 when transient floods and harrowing occurred. The predominant species were Aedes \\ scapularis, Culex nigripalpus and Cx. mollis. The Pilosus Group of Culex (Melanoconion) was \\ found at lower densities. Some epidemiological considerations are presented.
}

Keywords: Mosquitoes. Ecology, vectors. Larva.

\section{Introduction}

It is recognized that rice irrigation systems create suitable habitats for some culicid species. This may be roughly brought out by focussing on the respective situations in the empty and flooded paddies. In the south-eastern region of S. Paulo State, Brazil, as has already been reported in a previous paper, the empty condition seems to be propitious for Aedes scapularis production and for some Culex (Culex) mosquitoes and the permanent flooding favours Anopheles albitarsis breeding (Forattini et al., ${ }^{4,6}, 1994$ ).

The mosquito breeding production in the paddies was followed through during the 19931994 rice cultivation cycle at the Ribeira Valley Experimental Station in Pariquera-Açu County. The observations made focussed on the condition of the empty rice fields called stages 1 and 2 , when they remained fallow, uncultivated, ploughed and graded with transient floods. These are part of the method used to harrow the earth, making it smooth and ready for the next phase

\footnotetext{
* $\quad$ Supported by "Fundação de Amparo à Pesquisa do Estado de São Paulo (FAPESP)" (Grant n. 90/3371-6).

** Department of Epidemiology, School of Public Health, University of S. Paulo. Taxonomic and Systematic Research in Medical Entomology Unit of the University of S. Paulo/(NUPTEM) - S. Paulo, SP - Brazil

** Department of Pathology, School of Medicine, University of S. Paulo - S. Paulo, SP - Brazil

Reprints: O.P.Forattini - Av. Dr. Arnaldo, 715 -01246-904S. Paulo, SP-Brazil

The publication of this article was supported by FAPESP (Proccess n. 94/0500-0).
}

that is the transplantation stage. In the present paper the breeding patterns of the more abundant species found in those paddy situations are reported.

\section{Material and Method}

The study area and the rice cultivation cycle have already been described in Forattini et al.,6, 1994. Larvae were collected weekly starting over the period from 17 May to 29 November 1993. That period covered 29 weeks that included twelve corresponding to stage 1 and seventeen corresponding to stage 2 . In accord with the routine already adopted, standard 500 ml dippers were used and the density was estimated as an average of the number of larvae collected per ten dips.

When the rice fields were empty, each remaining pool in the two contiguous paddies, also previously described (Forattini et al. ${ }^{6}$, 1994), received attention and was sampled in the search for immature specimens. The sampling of these residual pools was made to the limit of 180 dips per collection. The Climatology Section of the Campinas Agronomic Institute (Instituto Agronômico de Campinas) of S. Paulo State provided data on the climatic conditions during the period.

As has been stated, stage 1, corresponding to the field in its fallow, uncultivated state, lasted until August when it was followed by stage 2. The ploughing which then began was carried out continuously until October when transient floods and harrowing followed. For 
ease in presenting the results, the weeks were numbered in sequence, the first being that starting on 17 May.

\section{Results}

Over the twenty-nine successive weeks, 8,626 mosquito larvae were collected. Of that total, $7,805(90.5 \%)$ belonged to only three species, namely Aedes scapularis, Culex mollis and $C x$. nigripalpus. With regard to the others, $365(4.2 \%)$ of them were $C x$. (Melanoconion) the most frequently found and, among these, the Pilosus Group prevailed with 301 (3.5\%) of the total of larvae collected.

Predominant species - As has already been said, three species predominated in the collections making up more than ninety percent of the total larvae obtained, as follows:

$\begin{array}{ccc}\text { Species } & \mathrm{n} & \% \\ \text { Culex nigripalpus } & 4,785 & 61.3 \\ \text { Aedes scapularis } & 2,276 & 29.2 \\ \text { Culex mollis } & 744 & 9.5 \\ \text { Total } & 7,805 & 100.0\end{array}$

With regard to the periods corresponding to the two rice cultivation stages, the global monthly data on larvae densities are presented in Table. The weekly distributions of these data throughout the whole collecting time are presented in the
Figures 1 and 2. As may be observed, positive results were obtained only for stage 1 when the rice fields remained fallow and uncultivated. Associations with rainfall became reasonably clear as regards Ae. scapularis, but not so much so with Culex nigripalpus and $C x$. mollis (Figs. 1 and 2). A remarkable decrease occurred at the beginning of the ploughing activities during stage 2 , when practically only Ae. scapularis was found and was associated once again with rain (Fig. 1). In the second part of stage 2, transient floods and simultaneous harrowing occurred before December when permanent flooding set in. In that phase no more larvae were found.

Less frequent species - Besides the predominant species others were obtained which made up less than ten percent of the total larvae collected. Among them Culex (Melanoconion) of the Pilosus Group ( $C x$. innovator, $C x$. pilosus and $C x$. rooti) were the most frequent. As was observed with regard to the other species, these were found in the rice fields only during stage 1 and at the beginning of stage 2. Association with rainfall was suggestive, as is shown by the Figure 1 .

\section{Discussion}

This study addressed the question as to whether the empty rice field situation constituted a propitious mosquito breeding environment. This condition corresponded to stages 1 and 2 of the

Table. Densities of on some mosquito larvae in rice paddies during the empty period corresponding to stages 1 and 2 of the cultivation cycle (1993-1994).

\begin{tabular}{|c|c|c|c|c|c|c|c|c|c|}
\hline \multirow{2}{*}{$\begin{array}{l}\text { Periods } \\
\text { Months }\end{array}$} & \multicolumn{3}{|c|}{ Aedes scapularis } & \multicolumn{2}{|c|}{ Culex nigripalpus } & \multicolumn{2}{|c|}{ Culex mollis } & \multicolumn{2}{|c|}{ Total } \\
\hline & $\mathbf{R}$ & $\mathrm{N}$ & $\bar{D}$ & $\mathrm{~N}$ & $D$ & $\mathbf{N}$ & $D$ & $\mathbf{N}$ & $\mathrm{D}$ \\
\hline \multicolumn{10}{|c|}{ Stage 1 (fallow, uncultivated) } \\
\hline May & 27.0 & 246 & 6.9 & 3,651 & 102.8 & 147 & 4.1 & 4,044 & 113.9 \\
\hline June & 97.6 & 814 & 16.4 & 1,120 & 22.5 & 594 & 12.0 & 2,528 & 51.1 \\
\hline July & 52.4 & 688 & 36.6 & - & - & - & - & 688 & 36.6 \\
\hline August (first half) & 1.2 & 366 & 19.6 & 10 & 0.5 & 3 & 0.2 & 379 & 20.3 \\
\hline Subtotal & & 2,114 & 17.2 & 4,781 & 39.0 & 744 & 6.1 & 7,639 & 62.2 \\
\hline \multicolumn{10}{|l|}{ Stage 2 (ploughing) } \\
\hline August (second half) & 38.6 & 58 & 96.7 & 3 & 5.0 & - & - & 61 & 101.7 \\
\hline September & 167.0 & 102 & 4.9 & 1 & + & - & - & 103 & 5.0 \\
\hline October (first week) & 39.6 & 2 & 0.2 & $\cdot$ & - & - & - & 2 & 0.2 \\
\hline Subtotal & & 162 & 5.5 & 4 & 0.1 & - & - & 166 & 5.6 \\
\hline \multicolumn{10}{|c|}{$\begin{array}{c}\text { Stage } 2 \text { (transient flooding } \\
\text { and harrowing) }\end{array}$} \\
\hline October & 41.0 & - & - & - & - & - & - & - & - \\
\hline November & 28.2 & - & - & - & - & - & - & - & - \\
\hline Subtotal & & - & $\cdot$ & - & - & - & - & - & - \\
\hline Total & 492.6 & 2,276 & 14.9 & 4,785 & 31.3 & 744 & 4.9 & 7,805 & 51.1 \\
\hline
\end{tabular}




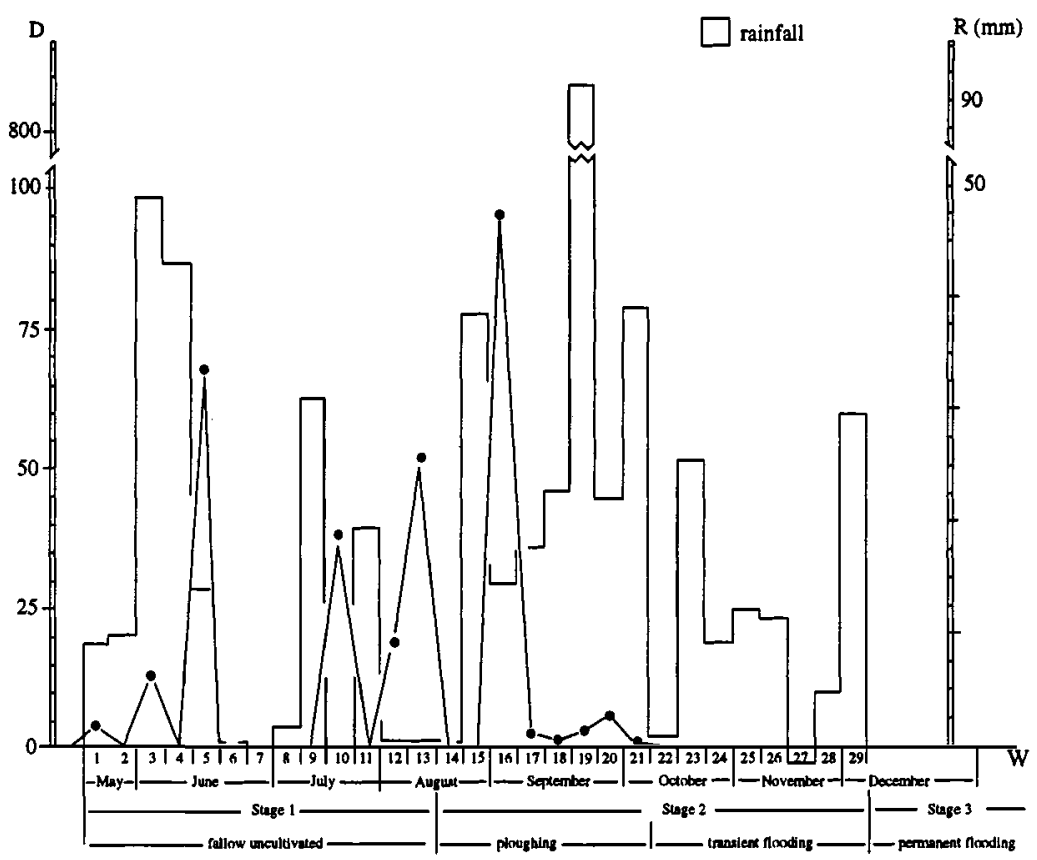

Figure 1. Weekly larvae densities of Ae. scapularis in the empty fields during stages 1 and 2. D - number of larvae per 10 dips. $R$ - rainfall $(\mathrm{mm}) \mathrm{W}$ - ordinal sequence of weekly samples during the rice cultivation cycle (1993-1994).

1993-1994 rice cultivation cycle in the study area. The results showed that some species were favoured by the fallow, uncultivated condition (stage 1) during the period prior to the ploughing that takes place during the first part of stage 2 . It seems that grading and flooding for harrowing do not favour mosquito breeding as, during that phase, no immature stages were found.

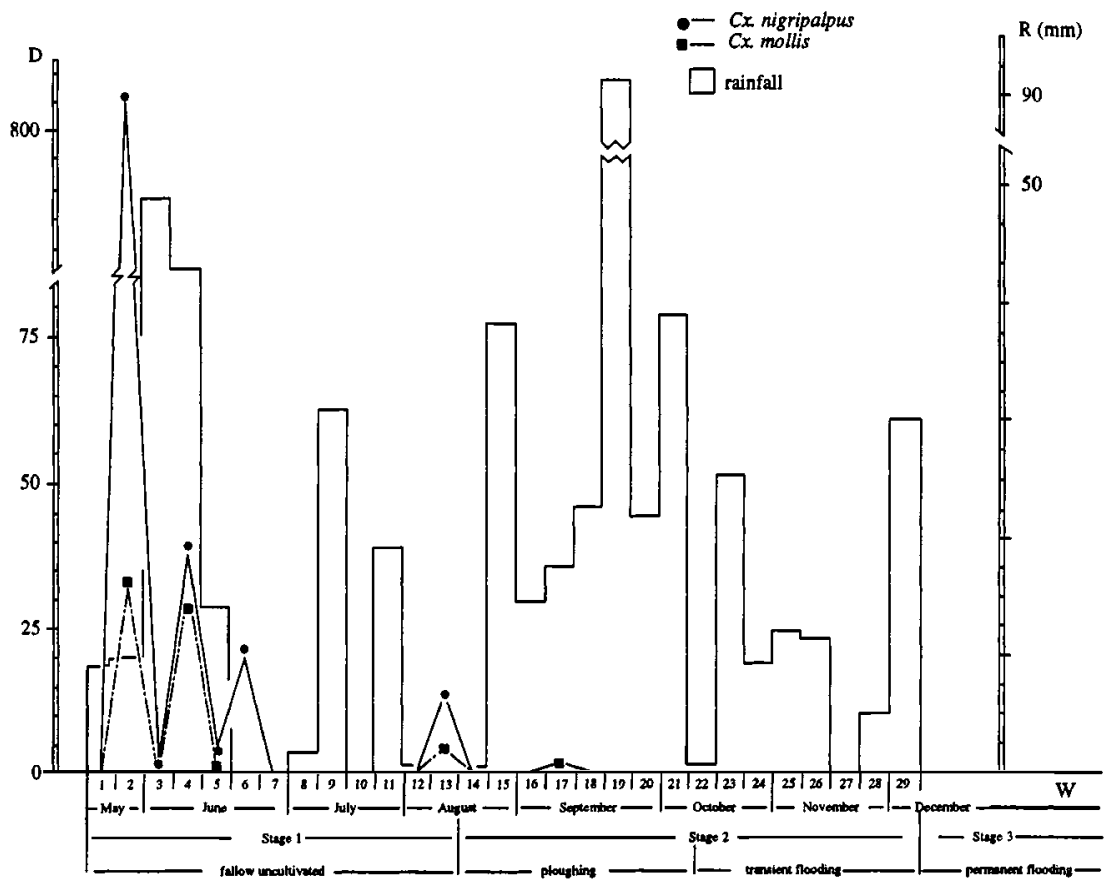

Figure 2. Weekly larvae densities of Culex in the empty rice fields during stages 1 and 2. D - number of larvae per 10 dips $R$ - rainfall (mm) W - ordinal sequence of weekly samples during the rice cultivation cycle (1993-1994). 
These field conditions seemed to provide suitable situations for the proliferation of Aedes scapularis, Culex nigripalpus and $C x$. mollis. It was suggestive that the habitat simplification and the niche reduction, both resulting from the rice field installation, favoured those mosquitoes, mainly during the fallow, uncultivated phase and, though less so, at the beginning of the ploughing phase. The association obtained with rainfall, was expected with regard to $A e$. scapularis, as shown in Figure 1. There the increased density following the heavier rainfall is evident. That behavior is normally presented by those culicidae that lay eggs in the empty breeding places and grow quickly from the hatching to the adult phase. Concerning Ae. scapularis, the influence of rainfall is more evident because it has drought-resistant eggs and utilizes ground-pools as breeding places. Besides, the results here obtained agree with the hypothesis that the species possesses a high degree of adaptability to man-made environments (Forattini et al. 2.4.5, 1986, 1993, 1994; Forattini and Gomes ${ }^{3}, 1988$ ).

Regarding the two Culex species named, the association with rainfall was not so clear (Fig. 2). Nevertheless, results obtained were suggestive as supporting the hypothesis that the amount of organic matter accumulating on the rice fields favoured the installation of suitable breeding places for these mosquitoes. Among them, Cx. nigripalpus showed a particular level of local adaptation to this environment (Forattini et al. $\left.{ }^{4,5}, 1993,1994\right)$.

As for the Pilosus Group of Culex (Melanoconion), the larvae were found prior to the end of the ploughing phase and their association with rainfall was suggestive (Fig. 3 ). Nevertheless, it was different from that presented by $A e$. scapularis since the increase of densities occurred almost concomitantly with the more intense rainfall. These culicidae lay resting eggs on moist substracts and remain viable, hatching when flooding occurs (Mattingly ${ }^{7}, 1976$ ). Thus this aspect, as well as the lengthy breeding time, may explain the different pattern found.

In conclusion, mosquito breeding in rice fields varies essentially in accordance with the three distinct parts of the rice cultivation cycle. The first one is that here considered as the empty phase and includes stage 1 and the ploughing phase of stage 2 (Forattini et al. ${ }^{4}, 1993$ ). At that time the fallow, uncultivated, ploughing and rainfall conditions provide suitable breeding

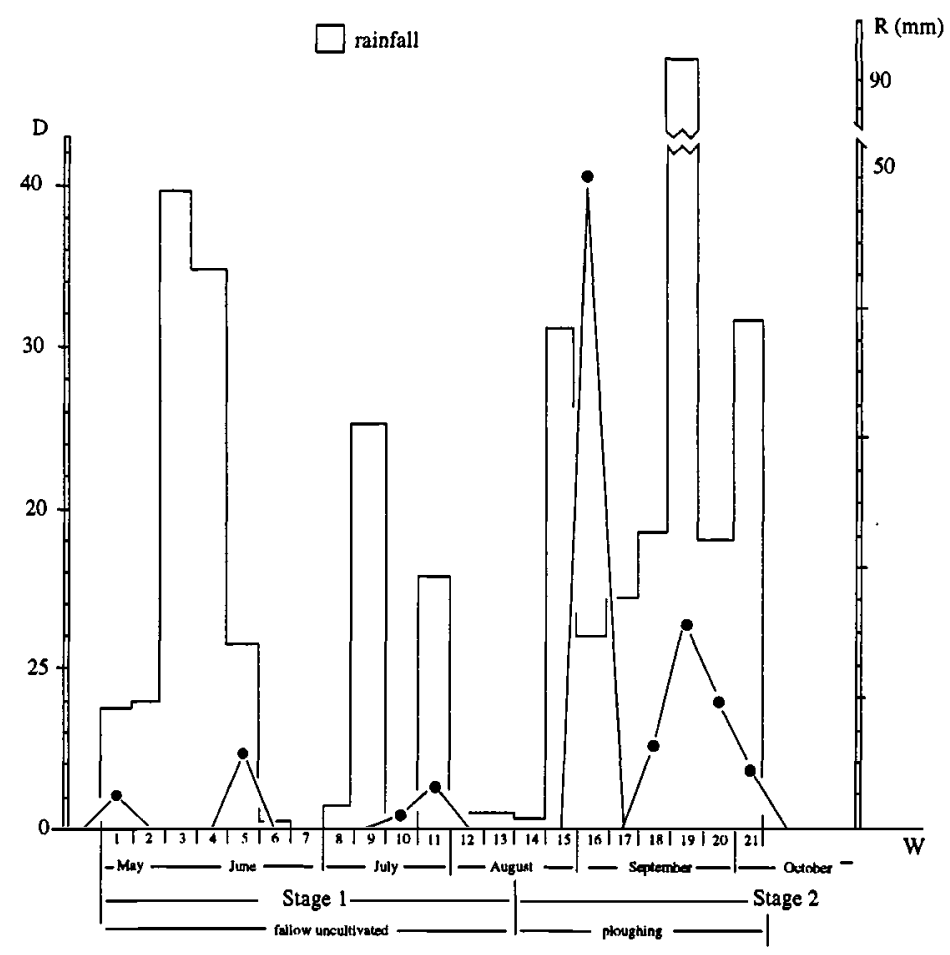

Figure 3. Weekly larvae densities of Pilosus Group of Culex (Melanoconion) in the empty rice fields during satage 1 and the first part of stage 2. D - number of larvae per 10 dips $R$ - rainfall $(\mathrm{mm}) \mathrm{W}$ - ordinal sequence of weekly samples during the rice cultivation cycle (1993-1994). 
places for Ae. scapularis, Cx. nigripalpus and $C x$. mollis. Depending on the rainfall intensity, the Pilosus Group of Culex (Melanoconion) may also increase in density. After the ploughing of stage 2 a second part occurs that includes transient flooding and harrowing. This seems unsuitable for mosquito breeding. Finally, the third part, corresponding to transplantation and permanent flooding (stages 3 and 4 ), converts the rice paddies into great breeding places for other mosquitoes, among them the Anopheles albitarsis, a local species important from the epidemiological point of view as a potential malaria vector (Forattini et al. ${ }^{6}, 1994$ ).

Nevertheless it is opportune to mention that the empty field condition may propitiate the breeding of species that may be of local epidemiological significance. So Ae. scapularis is recognized as widespread in South America and with a clear endophilic and domiciliary tendency. Some observations suggested that it may be involved in a chain of secondary transmission of Venezuelan equine encephalitis (Mitchell et al. ${ }^{8}$, 1985). Likewise, Cx. nigripalpus even though considered ornithophilic, has been indicated as a possible vector of the Saint Louis encephalitis virus (Cupp et al. ${ }^{1}, 1986$ ). Thus, it should be understood that, depending on the extent of the area under rice cultivation, the density of these mosquitoes may will constitute a public health problem.

FORATTINI, O.P. et al. Estudos sobre mosquitos (Diptera: Culicidae) e ambiente antrópico. 6-Observações em campos de arroz não cultivados, na região sudeste do Brasil. Rev.Saúde Pública, 28: 395-9, 1994. Apresentamse os resultados obtidos com a pesquisa sistemática de criadouros nas fases não cultivadas dos campos de arroz, correspondendo ao período de maio a novembro de 1993. Esse lapso de tempo foi o referente aos estádios de repouso, de aradura do terreno e de gradeamento. Este foi realizado mediante inundações transitórias e a homogeneização mecânica da terra. O primeiro correspondeu ao estádio 1, enquanto os outros dois, ao estádio 2. Foram encontrados criadouros nas etapas concernentes aos estados de repouso e de aradura. Foram negativas as pesquisas referentes às fases de gradeamento. As espécies predominantes foram Aedes scapularis, Culex nigripalpus e $C x$. mollis. Observou-se a existência de associações com o ritmo local das precipitações atmosféricas. São apresentadas considerações sobre o potencial epidemiológico desses encontros.

Descritores: Mosquitos. Ecologia de vetores. Larva.

\section{References}

1. CUPP, E.W.; SCHERER, W.F.; LOK, J.B.; BRENNER, R. J.; DZIEM, G.M.; ORDONEZ, J.V. Entomological studies at an enzootic Venezuelan equine encephalitis virus focus in Guatemala, 1977-1980. Am. J. Trop. Med. Hyg., 35:851-9, 1986.

2. FORATTINI, O.P.; GOMES, A. de C.; NATAL, D.; SANTOS, J.L.F. Observações sobre atividade de mosquitos Culicidae em matas primitivas da planície e perfis epidemiológicos de vários ambientes no Vale do Ribeira, São Paulo, Brasil. Rev. Saúde Pública, 20:178-203, 1986.

3. FORATTINI, O.P. \& GOMES, A. de C. Biting activity of Aedes scapularis (Rondani) and Haemagogus mosquitoes in Southern Brazil (Diptera: Culicidae). Rev. Saúde Pública, 22:84-93, 1988.

4. FORATTINI, O.P.; KAKITANI, I.; MASSAD, E.; MARUCCI, D. Studies on mosquitoes (Diptera: Culicidae) and anthropic environment. 2 - Immature stages research at a rice irrigation system location in South-Eastem Brazil. Rev. Saúde Pública, 27:227-36, 1993.

5. FORATTINI, O.P.; KAKITANI, I.; MASSAD, E.; MARUCCI, D. Studies on mosquitoes (Diptera: Culicidae) and anthropic environment. 3 - Survey of adult stages at the rice irrigation system and the emergence of Anopheles albitarsis in South-Eastern, Brazil. Rev. Saúde Pública, 27:313-25, 1993.

6. FORATTINI, O.P.; KAKITANI, I.; MASSAD, E.; MARUCCI, D. Studies on mosquitoes (Diptera: Culicidae) and anthropic environment. 5 - Breeding of Anopheles albitarsis in flooded rice fields in SouthEastern Brazil. Rev. Saúde Pública, 28: 329-31, 1994.

7. MATTINGLY, P.F. Mosquito eggs. XXVIII - Culex subgenera Melanoconion and Mochlostyrax. Mosq. Syst., 8:223-31, 1976.

8. MITCHELL, C.J.; MONATH, T.P.; SABATTINI, M.S.; CROPP, C.B.; DAFFNER, J.F.; CALISHER, C.H.; JAKOB, W.L.; CHRISTENSEN, H.A. Arbovirus investigation in Argentina, 1977-1980. II - Arthropod collections and virus isolations from Argentinian mosquitoes. Amer. J. Trop. Med. Hyg., 34: 945-55, 1985. 